http://jmscr.igmpublication.org/home/

ISSN (e)-2347-176x ISSN (p) 2455-0450

crossref DOI: https://dx.doi.org/10.18535/jmscr/v9i6.21

Journal Of Medical Science And Clinical Research

\title{
EVALUATION OF ACUTE TOXICITY STUDY OF CIVAKARANTHAI ILAI CÜRANAM
}

Authors

\author{
Sankarlatha $\mathbf{P}^{1}$, Manoharan $\mathrm{A}^{\mathbf{2}^{*}}$, Santhanakumar $\mathbf{M}^{3}$ \\ ${ }^{1}$ PG Scholar, Department of Maruthuvam, GSMC, Palayamkottai- 627002,Tamilnadu \\ ${ }^{2}$ Professor, Head of the Department, Department of Pothumaruthuvam, GSMC, Palayamkottai-627002, Tamilnadu \\ ${ }^{3}$ Asst.Professor \& NSS Programme officer, Dept. of Pharmacology, Arulmigu Kalasalingam college of Pharmacy, \\ Krishnankovil, Srivilliputtur, Tamilnadu \\ Corresponding Author \\ Manoharan A
}

Abstract
The siddha medicine is among oldest system of medicine in India. The Civakaranthai ilai cūranam has been
mentioned in classical literature Gunapadam Mooligai Vaguppu for the management of cegana vatham and it has
been correlated symptoms in modern medicine in cervical spondylosis.
Objective: The objective of this study was to investigate the acute toxicity of siddha herbal formulation
Method: Acute toxicity of civakaranthai ilai cüranam (CKC) is carried out as per the OECD -423 guidelines on
the acute toxicity study were used in female albino Wister rats. The test drug CKC was administered single dose at
$5 \mathrm{mg} / \mathrm{kg}, 50 \mathrm{mg} / \mathrm{kg}, 300 \mathrm{mg} / \mathrm{kg}, 1000 \mathrm{mg} / \mathrm{kg}, 2000 \mathrm{mg} / \mathrm{kg}$ body weight of animal for 14 days administered all group of
treated animals.
Results: The results are assessed for detect the effect of civakaranthai ilai cüramam .In acute toxicity study there
is no mortality and behavioural changes are observed in treating the animals in civakaranthai ilai cüranam
(2000mg/kg) indicating the p value is less than 0.05.
Conclusion: There were no mortality was observed in civakaranthai ilai cūranam (CKC).So civakaranthai ilai
cüranam was safer and can be prescribed for therapeutic use in humans.
Keywords: civakaranthai ilai cüranam, Siddha medicine, Toxicity study.

\section{Introdution}

One such valuable Siddha drug is Civakaranthai (Sphaeranthus amaranthoides Burn.f) from Siddha literature Gunapadam mooligai vaguppu has varied uses. The species being an annual stars growing in the post monsoon months of December \& January, survives hardly for 5-6 months, and then is dried. (Sphaeranthus amaranthoides Burn. f) belongs to the family Compositae (Asteraceae).It is an erect branced annual herb, the stem and branches glabrous, bearing simple, alternate, toothed decurrently leaves on the stem and branches. Root fibrous clustered developed enough to hold the plant in the marshy soil.
Leaves are simple, alternate, estipulate 2.5-7.5 cms long and varying width, linear oblong, obtuse serrulate slightly decurrent glabrous. Head inflorescence, each head with few or more outer flowers female fertile and few inner flowers bisexual corolla tubular fertile or sterile.

\section{Materials and Methods \\ Materials}

\subsection{Collection and authentication}

The Civakaranthai illai collected from in and around areas of palayamkottai and thirunelveli, Tamilnadu and identified by the Medicinal 
botanist experts at Government Siddha Medical College and Hospital, Palayamkottai.

\section{Purification and preparation}

The adulterants from the raw drugs were removed, cleaned and dried in shades and grinded into chooranam.

\section{Objectives}

The aim of this Study is to evaluate the toxicity of the test substance CKC, when administered orally to Female Wister Rats with different doses, so as to provide a rational base for the evaluation of the toxicological risk to man and indicate potential target organs.

\section{Guidelines Followed}

(a) OECD Guidelines No. 423, The organization for Economic Co-operation and Development Panel of experts (OECD guidelines) defines acute toxicity as "the adverse effects occurring within a short time of administration of a single dose of a substance or multiple dose given within 24 hours

\section{Study Design and Controls}

1) Female Wister Ratsin controlled age and body weight were selected.

2) The test drug CKC was administered at 5 $\mathrm{mg} / \mathrm{kg}, 50 \mathrm{mg} / \mathrm{kg}, 300 \mathrm{mg} / \mathrm{kg}, 1000 \mathrm{mg} / \mathrm{kg}$, and $2000 \mathrm{mg} / \mathrm{kg}$ body weight of animal as suspension along with water.

3) The results were recorded on day 0 , with single oral dosing period of 14 days.

\section{Experimental Procedure}

\section{Animals}

A total of 15 Female Wister Rats with an approximate age of 6 weeks and purchased from CAP LABS Nagarkovil. The animals were used with approval of Institutional animal ethics committee (IAEC).The mean weights of Female Wister Rats were 100-150 g respectively. All animals underwent a period of 20 days of observation and acclimatization between the date of arrival and the start of treatment. All the rats had free access to a pelleted rat diet. The water was offered ad libitum in bottles. The test substance was administered orally. The Female Wister Rats belonging to the control group were treated with the vehicle (Water) at the same administration volume as the rest of the treatment groups.

Doses: The doses for the study were selected based on literature search and range finding study. Following the period of fasting, the animals were weighed and then drug was administered orally as single dose using a needle fitted onto a disposable syringe of approximate size at the following different doses.

Table: I Animal Dose Level

\begin{tabular}{|l|c|}
\hline GROUP & DOSE \\
\hline Group-I & $5 \mathrm{mg} / \mathrm{kg}$ \\
\hline Group-II & $50 \mathrm{mg} / \mathrm{kg}$ \\
\hline Group-III & $300 \mathrm{mg} / \mathrm{kg}$ \\
\hline Group-IV & $1000 \mathrm{mg} / \mathrm{kg}$ \\
\hline Group-V & $2000 \mathrm{mg} / \mathrm{kg}$ \\
\hline
\end{tabular}

The test item was administered as single dose. After single dose administration period, all animals were observed for 14days.

Dose Preparation: CKC was added in distilled water and completely dissolved to form oral for administration. The dose was prepared of a required concentration before dosing by dissolving, in distilled water. It was mixed well. The preparation for different doses was vary in concentrations to allow a constant dosage volume.

Administration: The test item was administered orally to each Female Wister rats as single dose using a needle fitted onto a disposable syringe of appropriate size at the following different doses. The concentration of CKC was adjusted according to its body weight. The volume was not exceeding $10 \mathrm{ml} / \mathrm{kg}$ bodyweight. Variability in test volume was minimized by adjusting the concentration to ensure a constant volume at all dose levels.

Observation Period: All animals were observed for any abnormal clinical signs and behavioral changes. The appearance, change and disappearance of these clinical signs, if any, were recorded for approximately 1.0, 3.0 and 4.0 hours post-dose on day of dosing and once daily thereafter for14 days. 
Mortality and Morbidity: All animals were observed daily once for mortality and morbidity at approximately 1.0, 3.0 and 4.0 hours post dose on day of dosing and twice daily (morning and afternoon) thereafter for 14 days

\section{Results}

Table No -II Physical and Behavioral Examinations

\begin{tabular}{|l|c|c|c|}
\hline Group no. & Dose $(\mathbf{m g} / \mathbf{k g})$ & Observation sign & No. of animal affected. \\
\hline Group-I & $5 \mathrm{mg} / \mathrm{kg}$ & Normal & 0 of 3 \\
\hline Group- II & $50 \mathrm{mg} / \mathrm{kg}$ & Normal & 0 of 3 \\
\hline Group-III & $300 \mathrm{mg} / \mathrm{kg}$ & Normal & 0 of 3 \\
\hline Group-IV & $1000 \mathrm{mg} / \mathrm{kg}$ & Normal & 0 of 3 \\
\hline Group-V & $2000 \mathrm{mg} / \mathrm{kg}$ & Normal & 0 of 3 \\
\hline
\end{tabular}

Statistical significance (p) calculated by one way ANOVA followed by Dennett's $(n=6) ;{ }^{n s} p>0.05,{ }^{*} p<0.05$, $* * p<0.01, * * * p<0.001$, calculated by comparing treated groups with control group

Data obtained in this study indicated ${ }^{\mathrm{ns}} \mathrm{p}>0.05$ no significance physical and behavioral signs of any toxicity due to administration of $C K C$ at the doses of $5 \mathrm{mg} / \mathrm{kg}, 50 \mathrm{mg} / \mathrm{kg}, 300 \mathrm{mg} / \mathrm{kg}, 1000 \mathrm{mg} / \mathrm{kg}$ and $2000 \mathrm{mg} / \mathrm{kg}$ to rats.

Table No III Home Cage Activity

\begin{tabular}{|c|c|c|c|c|c|c|}
\hline \multirow[t]{2}{*}{$\begin{array}{l}\text { Functional and } \\
\text { Behavioural observation }\end{array}$} & \multirow[t]{2}{*}{ Observation } & $\begin{array}{c}\text { 5mg/kg Group } \\
\text { (G-I) }\end{array}$ & $\begin{array}{c}50 \mathrm{mg} / \mathrm{kg} \\
(\mathrm{G}-\mathrm{II})\end{array}$ & $\begin{array}{c}300 \mathrm{mg} / \mathrm{kg} \\
(\mathrm{G}-\mathrm{III})\end{array}$ & $\begin{array}{c}\text { 1000mg/kg } \\
(\mathrm{G}-\mathrm{IV})\end{array}$ & $\begin{array}{c}2000 \mathrm{mg} / \mathrm{kg} \\
(\mathrm{G}-\mathrm{V})\end{array}$ \\
\hline & & Female $n=3$ & Female $n=3$ & Female $n=3$ & Female $n=3$ & Female $n=3$ \\
\hline Body position & Normal & 3 & 3 & 3 & 3 & 3 \\
\hline Respiration & Normal & 3 & 3 & 3 & 3 & 3 \\
\hline Clonic involuntary Movement & Normal & 3 & 3 & 3 & 3 & 3 \\
\hline Tonic involuntary Movement & Normal & 3 & 3 & 3 & 3 & 3 \\
\hline Palpebral closure & Normal & 3 & 3 & 3 & 3 & 3 \\
\hline Approach response & Normal & 3 & 3 & 3 & 3 & 3 \\
\hline Touch response & Normal & 3 & 3 & 3 & 3 & 3 \\
\hline Pinna reflex & Normal & 3 & 3 & 3 & 3 & 3 \\
\hline Tail pinch response & Normal & 3 & 3 & 3 & 3 & 3 \\
\hline
\end{tabular}

Statistical significance (p) calculated by one way ANOVA followed by Dennett's $(\mathrm{n}=6) ;{ }^{\mathrm{ns}} \mathrm{p}>0.05$, $* \mathrm{p}<0.05, * * \mathrm{p}<0.01, * * * \mathrm{p}<0.001$, calculated by comparing treated groups with control group. Data obtained in this study indicated ${ }^{\mathrm{ns}} \mathrm{p}>0.0505$ no significance changes in Home cage activity.

Table No IV: Hand Held Observation

\begin{tabular}{|c|c|c|c|c|c|c|c|}
\hline \multirow[t]{2}{*}{$\begin{array}{l}\text { Functional and } \\
\text { Behavioral } \\
\text { observation }\end{array}$} & \multirow[t]{2}{*}{ Observation } & Control & $\begin{array}{c}5 \mathrm{mg} / \mathrm{kg} \\
(\mathrm{G}-\mathrm{I})\end{array}$ & $\begin{array}{c}50 \\
\mathrm{mg} / \mathrm{kg} \\
(\mathrm{G}-\mathrm{II}) \\
\end{array}$ & $\begin{array}{c}\text { 300mg/kg } \\
\text { (G-III) }\end{array}$ & $\begin{array}{c}1000 \mathrm{mg} / \mathrm{kg} \\
(\mathrm{G}-\mathrm{IV})\end{array}$ & $\begin{array}{c}2000 \mathrm{mg} / \mathrm{kg} \\
(\mathrm{G}-\mathrm{V})\end{array}$ \\
\hline & & Female $n=3$ & Female $n=3$ & Female $n=3$ & Female $n=3$ & Female $n=3$ & Female $n=3$ \\
\hline Reactivity & Normal & 3 & 3 & 3 & 3 & 3 & 3 \\
\hline Handling & Normal & 3 & 3 & 3 & 3 & 3 & 3 \\
\hline Palpebral closure & Normal & 3 & 3 & 3 & 3 & 3 & 3 \\
\hline Lacrimation & Normal & 3 & 3 & 3 & 3 & 3 & 3 \\
\hline Salivation & Normal & 3 & 3 & 3 & 3 & 3 & 3 \\
\hline Piloerection & Normal & 3 & 3 & 3 & 3 & 3 & 3 \\
\hline Pupillary reflex & Normal & 3 & 3 & 3 & 3 & 3 & 3 \\
\hline Abdominal tone & Normal & 3 & 3 & 3 & 3 & 3 & 3 \\
\hline Limb tone & Normal & 3 & 3 & 3 & 3 & 3 & 3 \\
\hline
\end{tabular}

Statistical significance (p) calculated by one way ANOVA followed by Dennett's $(n=6) ;{ }^{n s} p>0.05,{ }^{*} p<0.05$, $* * p<0.01, * * * p<0.001$, calculated by comparing treated groups with control group

Data obtained in this study indicated ${ }^{\mathrm{ns}} \mathrm{p}>0.05$ no significance changes in hand held observation and signs of any toxicity due to administration of $C K C$ at the doses of $5 \mathrm{mg} / \mathrm{kg}, 50 \mathrm{mg} / \mathrm{kg}, 300 \mathrm{mg} / \mathrm{kg}, 1000 \mathrm{mg} / \mathrm{kg}$ and $2000 \mathrm{mg} / \mathrm{kg}$ to rats. 
Table No-4 Mortality

\begin{tabular}{|l|c|c|}
\hline Group no & Dose no(mg/kg) & Mortality \\
\hline Group-I & $5(\mathrm{mg} / \mathrm{kg})$ & 0 of 3 \\
\hline Group-II & $50(\mathrm{mg} / \mathrm{kg})$ & 0 of 3 \\
\hline Group-III & $300(\mathrm{mg} / \mathrm{kg})$ & 0 of 3 \\
\hline Group-IV & $1000(\mathrm{mg} / \mathrm{kg})$ & 0 of 3 \\
\hline Group-V & $2000(\mathrm{mg} / \mathrm{kg})$ & 0 of 3 \\
\hline
\end{tabular}

Statistical significance (p) calculated by one way ANOVA followed by Dennett's $(n=6) ;{ }^{n s} p>0.05,{ }^{*} p<0.05$, $* * p<0.01, * * * p<0.001$, calculated by comparing treated groups with control group From acute toxicity study it was observed ${ }^{\mathrm{ns}} \mathrm{p}>0.05$ that the administration of $C K C$ at a dose of $2000 \mathrm{mg} / \mathrm{kg}$ to the rats do not produce drug-related toxicity and mortality. So No-Observed-Adverse-Effect- Level (NOAEL) at $C K C$ is $2000 \mathrm{mg} / \mathrm{kg}$.

\section{Discussion}

The evaluation of acute toxicity in female wister albino rat was the highest overall concord of toxicity in animals. Scientific knowledge towards oral toxicity of siddha medicine is needed and it also helps identify the doses.In the acute toxicity of Siddha formulation CKC administrated at the dose of $2000 \mathrm{mg} / \mathrm{kg}$ by oral route and was observed for 14 days. The acute toxicity of civakaranthai ilai cūranam was carried out as per OECD-423 guidelines, no death was observed in both the animal groups which is control group and animals treated with maximum dose of 2000 $\mathrm{mg} / \mathrm{kg}$. Treated animals showed no evidence of toxicity. There is no evidence of behavioral performance, lacrimation, salivation, pupilaryreflex, abdominal and limb tone. There were no abnormalities in body position, touch and tail pinch response.

\section{Conclusion}

In conclusion no toxic effect was observed upto $2000 \mathrm{mg} / \mathrm{kg}$ of Civakaranthai ilai cūranam (CKC) in Acute toxicity study. so, it can be concluded that the Civakaranthai ilai cüranam $(C K C)$ can be prescribed for therapeutic use in human.

\section{References}

1. Anbarasu. K, Yugi Vaithiya Sinthamani $8002^{\text {nd }}$ edition, Pg. no:106.

2. Murugesa Mudaliyar, Gunapadam Mooligai Vaguppu,Edition2008,228.

3. Nithya. I, Pitchiahkumar. M, Visweswaran.S, Evaluation of Acute toxicity study of Siddha drug
Eachuramooli Chooranam, Int. J. Adv. Res. Biol. Sci. (2019).6 (12):126-130.

4. S.N. Yoganarasimhan medicinal plants of india Volume.2,.1425.

5. Sumayya. M, Manoharan. A, Acute And Chronic Toxicity Study of Siddha Herbal Formulation Nelli Kudineer Samulam, Indian Journal Of Applied Research, Volume -9,Issue-4,April-2019,ISSN No 2249-555X.

6. T.V.S. Sambasivampillai Tamil and English dictionary.Vol-3,pg.no:2206. 